Research Article

\title{
Comparative Analyses of Diversity and Similarity Indices of West Bank Forest and Block A Forest of the International Institute of Tropical Agriculture (IITA) Ibadan, Oyo State, Nigeria
}

\author{
Ariyo Oluyinka Christopher \\ Department of Vocational and Technical Studies, Federal College of Forestry Mechanization, P. M. B. 2273, Afaka, \\ Kaduna State, Nigeria
}

Correspondence should be addressed to Ariyo Oluyinka Christopher; ask4ariyo@yahoo.com

Received 2 November 2019; Accepted 8 January 2020; Published 31 March 2020

Academic Editor: Qing-Lai Dang

Copyright (c) 2020 Ariyo Oluyinka Christopher. This is an open access article distributed under the Creative Commons Attribution License, which permits unrestricted use, distribution, and reproduction in any medium, provided the original work is properly cited.

Comparative analyses of diversity and similarity indices of west bank and block A forest of the International Institute of Tropical Agriculture (IITA) were carried out by the vegetation survey using transects and plot sampling techniques. Six transects $\{A$ $\left(270^{\circ} \mathrm{W}\right), B\left(90^{\circ} \mathrm{E}\right), C\left(180^{\circ} \mathrm{S}\right), D, E\left(0^{\circ} \mathrm{N}\right)$, and $\left.F\left(180^{\circ} \mathrm{W}\right)\right\}$ were constructed with the aid of prismatic compass in west bank forest and block A forest. 10 sampling plots of $10 \mathrm{~m} \times 10 \mathrm{~m}$ were demarcated along each transect making 30 plots in each forest, and a total number of 60 plots were used for the study. Complete enumeration and identification of plants were carried out in each plot. The results showed that block A forest had 167 plant species from 58 families while west bank forest had 146 plant species from 56 families. A total number of 219 plant species from 70 families and 5804 individual plants were recorded in the two forests. West bank forest had higher values of all the diversity indices and Gamma diversity except Margalef s community diversity index and alpha diversity index which were high in block A forest. Sorensen's and Jaccard similarity indices of plants between west bank forest and block A forest were $59.42 \%$ and $42.66 \%$, while the dissimilarity index of $40.58 \%$ was recorded. Thus, the two forests are richer and diverse in plant species; adequate protection of the two forests should be a priority to prevent loss of diversity of plants. Cutting of poles from the forests should be stopped.

\section{Introduction}

Biodiversity is the totality of heritable variations or differences in characteristics that exist in all living things, individuals, and their species in various ecosystems in different parts of the earth [1]. According to the Convention on Biological Diversity [2], biodiversity is defined as "the variability among living organisms from all sources including inter alia, terrestrial, marine, and other aquatic ecosystems, and the ecological complexes of which they are a part of; this includes diversity within species, between species, and of ecosystems." Moreover, biodiversity has become an increasingly popular topic within the discussion of sustainability in the last decade, though the maintenance of diversity of forest ecosystems is required since many years $[3,4]$. This interesting topic was stressed especially in the Rio
Declaration and renewed by the Lisbon Conference in 1998 [5]. Generally, biodiversity measurement typically focuses on the species level, and species diversity is one of the most important indices which are used for the evaluation of ecosystems at different scales [6]. Local diversity can be studied with various indices, such as number of species per unit area (species richness) or the Shannon index, amongst others. These are used as indicators of the degree of complexity of the under study communities and provide information on the homeostatic capacity of the system to unforeseen environmental changes [7].

Distinguishing plant communities has been at the heart of vegetation science for centuries, with a traditional focus on the distribution, composition, and classification of plant communities [8]. Plant communities are defined as an assemblage of functionally similar species populations that 
occur together in time and space [7]. Plant communities are separated from each other based on indicator species in combination with a distinctive floristic composition. The latter is considered as one of the major distinguishing characters of a community, and therefore, any depletion of biodiversity is bound to alter the community attributes $[9,10]$.

Biodiversity includes genetic diversity, species richness, and ecosystem diversity and assumes that these are interdependent and quantified through taxonomic inventories within specified areas $[11,12]$. The number of different species within a geographical area depends on migration and adaptation to environmental conditions and how they in turn modify the environment $[13,14]$. Biological conservation is concerned with the protection of living species including the sustainable use of soils and environmental resources [15]. Biologists have long realized the value of biodiversity to humanity, but local communities also value biodiversity in their own terms for "use" and traditional conservation systems exist $[16,17]$. A range of species may have no direct value to people, but provide common ecological services to the wider community through tourism revenue and an ecosystem that is more sustainable.

The west bank and block A forests of the International Institute of Tropical Agriculture (IITA) are a mosaic of abandoned villages and farmland at various stages of forest regrowth. The plots that were under cultivation before the acquisition fifty three years ago are now mainly a thicket of Chromolaena odorata. It is interesting that although some tree saplings are now emerging through this undergrowth, there is so far little sign of the structure and diversity of the original primary forest. On the other hand, it is remarkable to note that many of the forest species of plants and animals have managed to survive or even flourish in this extended "bush fallow". The natural vegetation in this area could be classified as tropical semideciduous forest with various pockets of vegetation types ranging from derived savanna, secondary forest, and riparian types. According to Ezealor [18], the area resembles mature Guinea-Congo lowland rainforest with scattered emergence of trees which include Ceiba pentadra, Milicia excelsa, and Terminalia species. Large clumps of bamboo (Bambusa vulgaris) are common; stands of Raphia vinifera are found along watercourses while scattered oil palms Elaeis guineensis grow in both low-lying and the relatively better-drained upland areas.

The west bank forest had been under active protection as an informal forest and nature reserve for some years while block A forest are open to villagers living at the adjoining villages of IITA perimeter fence for collection of NonTimber Forest Products (NTFPs) such as firewood, bamboo, waterleaf, and palm kernel and also to IITA staff for collection of poles, pegs, and firewood for experimental field. Few authors have worked on the vegetation structural diversity and similarity index of west bank forest but no information is available on the comparative analysis of diversity and similarity indices of the two forests with the view of comparing the species composition, richness, diversity, and similarity of the two forests. It is against this backdrop this work was designed to compare the diversity and similarities indices of the two forests.

\section{Materials and Methods}

2.1. Study Area. The study areas are the west bank and block A forests of the International Institute of Tropical Agriculture (IITA), Ibadan, Oyo State, Nigeria. IITA is located at longitude $7^{\circ} 30^{\prime} 8^{\prime \prime} \mathrm{N}$, latitude $3^{\circ} 54^{\prime} 37^{\prime \prime} \mathrm{E}$, and $243 \mathrm{~m}$ above sea level [19]. The site falls within humid tropical lowland region with two distinct seasons: the longer wet season and shorter dry season. The wet season lasts for eight months, and it extends from March to October while the dry season lasts for four months from November to February. The rainfall pattern is bimodal with an annual total which ranges from 1,300 to $1,500 \mathrm{~mm}$ most of which falls between May and September. The average daily temperature ranges between $21^{\circ} \mathrm{C}$ and $23^{\circ} \mathrm{C}$, while the maximum is between $28^{\circ} \mathrm{C}$ and $34^{\circ} \mathrm{C}$. Radiation is about $5285 \mathrm{MJ} / \mathrm{m}^{2} /$ year. Mean relative humidity is in the range of $64 \%$ to $83 \%$ [19].

2.2. Data Collection. The method of data collection for this study was based on vegetation survey using transects and plot sampling techniques [20-26].

2.3. Transects and Plot Designs. Six transects $\left\{A\left(270^{\circ} \mathrm{W}\right), B\right.$ $\left(90^{\circ} \mathrm{E}\right), C\left(180^{\circ} \mathrm{S}\right), D, E\left(0^{\circ} \mathrm{N}\right)$, and $\left.F\left(180^{\circ} \mathrm{W}\right)\right\}$ were constructed with the aid of prismatic compass in west bank forest and block A forest of IITA. The transects were established with minimal disruption to the environment and marked with flagging tape at every $10 \mathrm{~m}$. Each transect was $500 \mathrm{~m}$ long. 10 sampling plots of $10 \mathrm{~m}$ by $10 \mathrm{~m}$ each were demarcated along each of the transect making a total number of 60 sampling plots (6 transects by 10 plots). A distance of $40 \mathrm{~m}$ was left between each of the plot to minimize repetition of plant species, while $20 \mathrm{~m}$ was left at the beginning and at the end of each transect as the border row to minimize edge effects (Figure 1). Complete enumeration and identification of plants were carried out in each plot. The identification of plant species was carried out with the assistance of a retired taxonomist from the Forestry Research Institute of Nigeria. Samples of plants that cannot be identified on the field were coded and taken to the Forestry Research Institute of Nigeria, Ibadan (FRIN) herbarium, for proper identification. The number of individuals of each species and the total number of plants were recorded. The geographical positioning system (GPS) was used to take the coordinates of the plots and transects; this was plotted on the GPS arc view to know the position of each transect within the two forests and to obtain the study location map (Figures 2 and 3).

2.4. Data Analysis. The data were analyzed using diversity indices and similarity indices. 


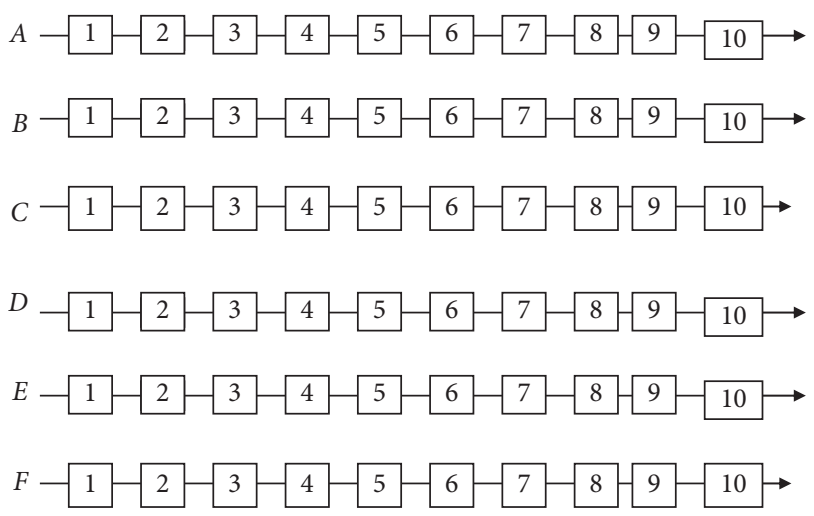

Each line $A, B, C, D$ are $500 \mathrm{~m}$ long transect while $1,2,3,--\cdot----10$ are plots of $10 \mathrm{~m}$ by $10 \mathrm{~m}$ each.

FIgURE 1: Transects and plot design.

2.4.1. Diversity Indices. Three levels of diversities have been distinguished. These are alpha, beta, and gamma diversities $[27,28]$. Community studies vary in the number of species encountered in a sample (alpha diversity) and in the total number of species encountered in a study (gamma diversity) [28]. For the measurement of diversity, the Alpha (Simpson diversity index) and Beta (Sorensen similarities indices) diversities were used to determine and compare the plant species diversity of the two sites. The diversity indices of plant community were computed on the basis of density values or total number of individuals of the plants in all the transects and in west bank and block A forests. Seven different indices for describing the species diversity have been devised by various scientists:

(i) Simpson's diversity index $D$ [29] was calculated using the following formula:

$$
D=\frac{\sum n i(n i-1)}{N(N-1)}
$$

where $n i$ is the total number of each species and $N$ is the total number of all the species.

(ii) The Shannon and Weiner index $\left(H^{\prime}\right)$ was computed from the formula as modified by Shannon and Weiner [30]:

$$
H \prime=\frac{-3.3219 \sum n i}{N \log (n i / N)}
$$

where $n i$ is the total number of each species and $N$ is the total number of all the species.

(iii) The evenness $(E)$ was computed from Pielou's index [31]:

$$
E=\frac{H^{\prime}}{\ln S}
$$

where $H^{\prime}=$ Shannon and Weiner diversity and $\ln S$ is the natural $\log$ of the total number of species recorded. (iv) Margalef's community diversity index was calculated by using the formula given by Margalef [32]:

$$
d=\frac{S-1}{\log N}
$$

where $S=$ total number of species and $N=$ total number of individuals.

(v) The McIntoch diversity index was calculated using the formula given by McIntosh [33]:

$$
\mathrm{DI}=\sum \sqrt{S * n i^{2}}
$$

where $S$ is the total number of species and $n i$ is the number of individual species.

(vi) The Menhinick diversity index was calculated by using the formula given by Menhinick [34]:

$$
d=\frac{S}{\sqrt{N}},
$$

where $S$ is the total number of species and $N$ is the total number of individuals.

(vii) The concentration of dominance $\left(C_{\mathrm{d}}\right)$ was calculated by using the formula given by Simpson [29]:

$$
C_{\mathrm{d}}=\left(\frac{N_{i}}{N}\right) 2,
$$

where $N i=$ proportion of individual belonging to $i$ th species and $N=$ total number of individuals.

2.4.2. Similarity Indices (SI). The similarity index determines the interspecific association between the species of plant communities. Sorensen similarity index [35] and Jaccard similarity index were used to determine and compare the similarities of plant species in transects $A$ and $B, A$ and $C, A$ and $D, A$ and $E, A$ and $F, B$ and $C, B$ and $D, B$ and $E, B$ and $F, C$ and $D, C$ and $E, C$ and $F, D$ and $E, D$ and $F$, $E$ and $F$, and SA and SB (site $A$ : west bank forest and site $B$ : block A forest) because the plots and transects are of equal sizes.

(viii) Sorensen's species similarity index (SI) between the transects and the two sites was calculated according to Nath et. al. [36]:

$$
\mathrm{SI}=\left(\frac{2 C}{(a+b)}\right) * 100 \text {, }
$$

where $C$ is the number of species in sites $a$ and $b ; a$ and $b$ are the number of species in sites $a$ and $b$.

(ix) Jaccard similarity index $\left(C_{j}\right)$ between the transects and the two sites was calculated following Magurran [37]:

$$
C_{j}=\frac{a}{(a+b+c)},
$$




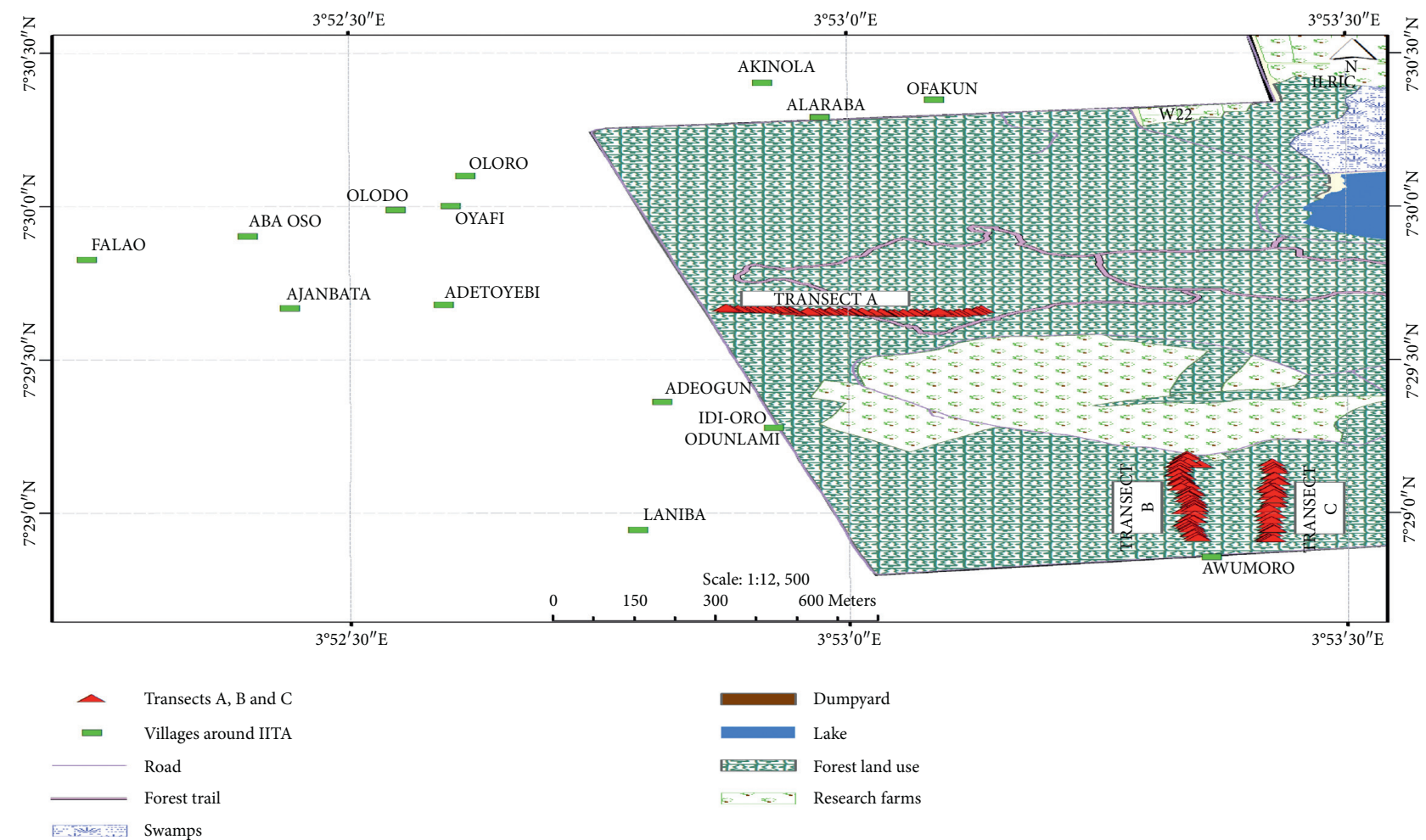

Figure 2: Map of west bank forest showing the location of transects $A, B$, and $C$.

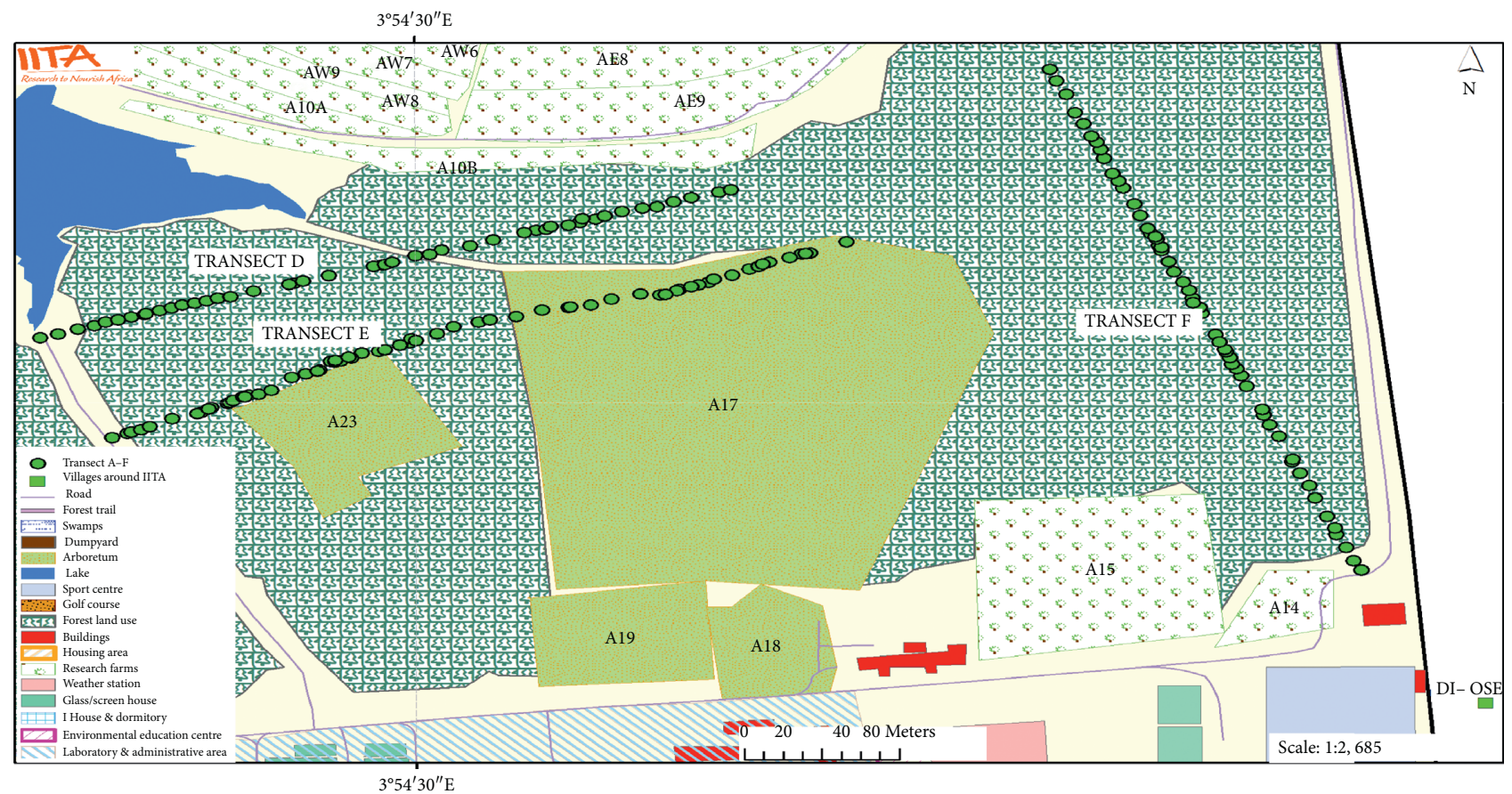

Figure 3: Map of block A forest showing the location of transects $D, E$, and $F$.

where $a$ is the number of species common to both sites (site $A$ : west bank forest and site $B$ : block A forest), $b$ is the number of species in site $A$ not in site $B$ (species in transect $A$ not in transect $B$ ), and $c$ is the number of species in site $B$ not in site $A$ (species in transect $B$ not in transect $A$ ). (x) Dissimilarity index (DI) is the reverse sequence of similarity index. It was calculated by the following formula:

$$
\mathrm{DI}=1-\mathrm{SI} \text {, }
$$

where SI is the similarity index. 


\section{Results and Discussion}

3.1. Diversity Indices of Plant Community in the West Bank and Block A Forests. Species diversity is a useful parameter for the comparison of communities under the influence of biotic disturbances or to know the state of succession and stability in the community [38]. The diversity indices of plant community in all the transects are depicted in Table 1. The Simpson index value ranges from 0.00142 to 0.02260 . Transect $A$ had the highest plant diversity index of 0.00619 , transects $D$ and $B$ had 0.00710 and 0.00858 , respectively, and transects $E$ and $C$ had 0.01072 and 0.01198 . Transect $F$ had the least Simpson diversity index of 0.02260 . It follows that transect $A$ was richer in plant species than all other transects, followed by transects $D, B, E$, and $C$ and lastly transect $F$. West bank forest consisting of transects $A, B$, and $C$ was more richer in plant species with the value of 0.00215 index compared with block A forest (transects $D, E$, and $F$ ) which had a Simpson diversity index of 0.00391 . The results of the two forests (west bank forest and block A forest) combined together gave a much higher Simpson diversity index of 0.00142. The Simpson diversity index was however low when compared with the value of over 0.90 obtained for the species-rich evergreen forests of the Western Ghats [39].

The Shannon-Weiner and evenness indices were high for transects $A, D$, and $B$ with the values of 0.28947 and $0.14603,0.30150$ and 0.15142 , and 0.31886 and 0.16198 , respectively. Transects $E$ and $C$ had Shannon-Weiner and evenness indices in the order of 0.33962 and $0.16945,0.34291$ and 0.17221 , while transect $F$ had the least value of 0.41198 and 0.21587 , respectively. West bank forest gave higher Shannon-Weiner and evenness indices of 0.20587 and 0.09512 , and least values of 0.25042 and 0.11266 were recorded for block A forest. However, pooling the results of the two forest together gave a much higher value of 0.17840 and 0.07622 , respectively.

Margalef's community diversity index was higher for transects $E, C, D$, and $A$ with the values of $33.48,32.70,31.66$, and 30.80, respectively, while transects $B$ and $F$ had the lowest indices of 30.67 and 29.31. Block A forest was higher (48.46) in Margalef's diversity index than west bank forest (41.47). Both forests combined gave Margalef's diversity index of 57.92. The McIntoch diversity index recorded $11894.72,11463.62$, and 9758.43 for transects $A, D$, and $E$. Transects $B, C$, and $F$ had indices of $9634.01,9166.93$, and 4824, respectively. West bank forest showed a higher McIntoch diversity index of 37928.68 than block A forest which had 34439.39. A value of 85891.36 index was observed for both west bank and block A forest.

Menhinick diversity index values of 2.75526, 2.87986, 2.94239, and 3.22048 were recorded for transects $A, D, B$, and $C$ while 3.24124 and 3.49867 were for transects $E$ and $F$. This index was high (2.60590) for west bank forest and low (3.23495) for block A forest. An index of 2.87462 was observed for both west bank and block A forest combined together. The concentration of dominance were high for transects $A, D, B$, and $E$ with $0.00625,0.00716,0.00867$, and 0.01082 , respectively. Transects $C$ and $F$ had the least concentration dominance of 0.01120 and 0.02284 . West bank forest and block A forest had 0.00216 and 0.00393, respectively. The two forests combined together had the concentration dominance of 0.00142 . The results of these indices were higher than the findings of Ekta [38] which recorded average values of $0.44,2.66,0.32,0.30,11.05$, and 3296.58 for Simpson diversity index, Shannon and Weiner diversity index, evenness index, concentration dominance, Margalef's diversity index, and McIntosh diversity index for vegetation around sewage drains.

In terms of intraspecies (alpha diversity), transect $E$ had the highest diversity (101 species), followed by transects $C$ and $D$ which had equal diversity of 98 species. Transects $A, B$, and $D$ had alpha diversity of 96 species, 93 species, and 81 plant species, respectively. However, block A forest (transects $D, E$, and $F$ ) showed higher alpha diversity of 167 plant species from 58 families than west bank forest (transects $A$, $B$, and $C$ ) which had 146 plant species from 56 families. In terms of Gamma diversity (individual species), transect $A$ recorded the highest diversity of 1214 plants followed by transects $D(1158)$ and $B$ (999) while transects $C, E$, and $F$ had 971, 926, and 536 plants, respectively. West bank forest showed a higher gamma diversity of 3139 plants than block A forest which had 2665 plants. A total number of 219 plant species from 70 families and 5804 plants were recorded as alpha and gamma diversities for the two forests. West bank forest which had higher values of all the diversity indices and Gamma diversity except Margalef's community diversity index and alpha diversity index could be due to the protection which the forest has undergone over period of years while increase in Margalef s community diversity index and alpha index of block A forest could be due to dam and river which run through the side of the forest and floods which normally inundate the forest during the raining season from the outside fence. This creates riparian effect whereby there is enough moisture and favourable conditions for plant growth. According to Hengaveld [40], species diversity is an important attribute of a natural community that influences the functioning of an ecosystem. Ecosystem functioning according to De Groot et. al. [41] is the capacity of the natural process and components to provide goods and services that satisfy human needs, directly or indirectly. This simply implies that the higher the biodiversity, the more efficient the functioning of the ecosystem. Logging decreased the species diversity $[42,43]$; since logging was not allowed in both west bank forest and block A forest, species diversity was expected to be high. However, the results from the two forests showed a high diversity of plant species despite the disturbance that had occurred in the areas such as illegal hunting, land clearing for experiment, construction of physical structure, and firewood, poles, and stake collection [24, 44]. Mishra et. al. [10] reported that moderately or slightly disturbed tropical forest ecosystem tends to support more number of plant species in comparison with a forest which is dense and undisturbed. According to Isichei [45], succession restores and increases the diversity of life in an area after disturbance. Also Ayodele and Lameed [1] stated that species diversity is well correlated with the annual amount of rainfall with the water areas tending to be rich in species diversity in the southern parts of Nigeria. The 
TABLE 1: Diversity indices of plants community at west bank forest and block A forest of IITA

\begin{tabular}{|c|c|c|c|c|c|c|c|c|c|c|}
\hline Transects & $n$ & $N$ & $\begin{array}{l}\text { No. of } \\
\text { families }\end{array}$ & $\begin{array}{l}\text { Simpson } \\
(D)\end{array}$ & $\begin{array}{c}\text { Shannon-Weiner } \\
(H)\end{array}$ & $\begin{array}{l}\text { Evenness } \\
(E)\end{array}$ & $\begin{array}{l}\text { Margalef's } \\
\quad(d)\end{array}$ & $\begin{array}{c}\mathrm{Mc} \\
\text { Intoch } \\
(\mathrm{DI})\end{array}$ & $\begin{array}{l}\text { Menhinick } \\
\quad(d)\end{array}$ & $\begin{array}{c}\text { Concentration } \\
\text { of dominance }\left(C_{\mathrm{d}}\right)\end{array}$ \\
\hline$A$ & 96 & 1214 & & 0.00619 & 0.28947 & 0.14603 & 30.80 & 11894.72 & 2.75526 & 0.00625 \\
\hline$B$ & 93 & 999 & & 0.00858 & 0.31886 & 0.16198 & 30.67 & 9634.01 & 2.94239 & 0.00867 \\
\hline C & 98 & 926 & & 0.01198 & 0.34291 & 0.17221 & 32.70 & 9166.93 & 3.22048 & 0.01120 \\
\hline WBF & 146 & 3139 & 56 & 0.00215 & 0.20587 & 0.09512 & 41.47 & 37928.68 & 2.60590 & 0.00216 \\
\hline$D$ & 98 & 1158 & & 0.00710 & 0.30150 & 0.15142 & 31.66 & 11463.62 & 2.87986 & 0.00716 \\
\hline$E$ & 101 & 971 & & 0.01072 & 0.33962 & 0.16945 & 33.48 & 9758.43 & 3.24124 & 0.01082 \\
\hline$F$ & 81 & 536 & & 0.02260 & 0.41198 & 0.21587 & 29.31 & 4824 & 3.49867 & 0.02284 \\
\hline BAF & 167 & 2665 & 58 & 0.00391 & 0.25042 & 0.11266 & 48.46 & 34439.39 & 3.23495 & 0.00393 \\
\hline $\begin{array}{l}\text { WBF and } \\
\text { BAF }\end{array}$ & 219 & 5804 & 70 & 0.00142 & 0.17840 & 0.07622 & 57.92 & 85891.36 & 2.87462 & 0.00142 \\
\hline
\end{tabular}

Source: computed from vegetation survey data, 2017.

abundance of plant species in the forest reserves may be due to the combined effects of favourable climatic conditions and protection from anthropogenic activities over many years which enhance regeneration.

\subsection{Sorensen's Similarity Indices of Plant Species in West Bank} and Block A Forest. Table 2 shows Sorensen's similarity indices of each transect and the two forests. Beta diversity which compares the similarity between transects as suggested by Wolda [20], Ariyo [44], and Ariyo et al. [24] showed that Sorensen's similarity indices of each transect and the two forests varied from $70.90 \%$ to $48.45 \%$ for transects $A$ and $B$, and $A$ and $D$, respectively. Transects $A$ and $B$ had the highest similarity indices of $70.90 \%$ followed by transects $B$ and $C$, and $A$ and $D$ which had $68.06 \%$ and $67.01 \%$. Transects $B$ and $E, B$ and $F, D$ and $E$, and $A$ and $E$ had $58.76 \%, 57.47 \%, 55.28 \%$, and $54.82 \%$, respectively. An equal value of $53.63 \%$ was recorded for transects $C$ and $F$ and $D$ and $F$, while transects $C$ and $E, A$ and $F$ had $53.27 \%$ and $53.12 \%$, respectively. Sorensen's similarity index between west bank forest and block A forest and between transect $E$ and $F$ was $59.42 \%$ and $52.75 \%$. Transects $B$ and $D, C$ and $D$ had close values of $51.31 \%$ and $51.02 \%$, while transects $A$ and $D$ had the least similarity index of $48.45 \%$. Transects $A$ and $B$ which had the highest percentage of Sorensen's similarity indices $(70.90 \%)$ are similar to each other in terms of plant species between the two transects. Transects $A$ and $B$ had 67 plant species in common, transect $A$ had 96 plant species, while transect $B$ had 93 plant species. Also, transect $A$ had 28 plant species that were not found in transect $B$ while transect $B$ had 26 plant species that were not found in transect $A$. West bank forest and block A forest had 93 plant species in common, west bank had 146 plant species, while block A forest had 167 plant species. Sorensen's similarity indices of plants between west bank forest and block A forest were high with a value of $59.42 \%$. The result generally showed that Sorensen's similarity indices of plants between all transects (apart from transects $A$ and $D$ ), west bank forest, and block A forest was high, above 50\%. Ariyo [44] and Ariyo et al. [24] found low similarities indices of plants less that $50 \%$ between the forests' transect apart from transects $B$ and $C$. According to Ekta [38], high similarity indices could be due to high
TABLE 2: Sorensen's similarity index of plant species in west bank and block A forest of IITA.

\begin{tabular}{lccccccc}
\hline Transect & $A$ & $B(\%)$ & $C(\%)$ & $D(\%)$ & $E(\%)$ & $F(\%)$ & BAF (\%) \\
\hline$A$ & $*$ & 70.90 & 67.01 & 48.45 & 54.82 & 53.12 & $*$ \\
$B$ & & $*$ & 68.06 & 51.31 & 58.76 & 57.47 & $*$ \\
$C$ & & & $*$ & 51.02 & 53.27 & 53.63 & $*$ \\
$D$ & & & & $*$ & 55.28 & 53.63 & $*$ \\
$E$ & & & & & $*$ & 52.75 & $*$ \\
$F$ & & & & & & $*$ & $*$ \\
WBF & & & & & & & 59.42 \\
\hline
\end{tabular}

Source: computed from vegetation survey data, 2017.

moisture content in soil, comparatively low temperature, bright light, and higher organic content through humification which mostly bring about uniformity in the weather conditions which results in good plant growth.

3.3. Jaccard Similarity Indices of Plant Species in West Bank and Block $A$ Forest. Jaccard similarity index of plant species on Table 3 shows that transects $A$ and $B, B$ and $C$, and $A$ and $C$ had values above $50 \%$ with transects $A$ and $B$ being the highest (55.37\%); this was followed by transects $B$ and $C$, and $A$ and $C$ which had $51.59 \%$ and $50.78 \%$. Transects $B$ and $F$, and $B$ and $E$ had low values of $40.32 \%$ and $40.14 \%$, respectively, while values less than $40 \%$ were recorded for transects $D$ and $E, A$ and $E, C$ and $F, D$ and $F, A$ and $F, C$ and $E, E$ and $F, B$ and $D, C$ and $D$, and $A$ and $D$, respectively. West bank and block $A$ forest recorded a Jaccard similarity index of 42.66\%. West bank forest and block A forest had 93 plant species in common, west bank forest had 52 plant species that were not found in block A forest, while block A forest had 73 plant species that were not found in west bank forest.

3.4. Dissimilarity Index of Plant Species in West Bank and Block A Forest of IITA. The dissimilarity index which is a reverse sequence of similarity index as found on Table 4 was high for transects $A$ and $D$ with $51.55 \%$. Transects $B$ and $E, A$ and $C, A$ and $E, A$ and $F, B$ and $C, B$ and $D, B$ and $F, C$ and $E$, $C$ and $F, D$ and $E, D$ and $F, E$ and $F$, and $C$ and $D$ had dissimilarity indices ranging between $41.24 \%$ and $48.98 \%$. West bank forest and block A forest had a dissimilarity index 
TABLE 3: Jaccard similarity index of plant species in west bank and block A forest of IITA.

\begin{tabular}{lccccccc}
\hline Transect & $A$ & $B(\%)$ & $C(\%)$ & $D(\%)$ & $E(\%)$ & $F(\%)$ & BAF (\%) \\
\hline$A$ & $*$ & 55.37 & 50.78 & 32.19 & 38.03 & 36.43 & $*$ \\
$B$ & & $*$ & 51.59 & 34.51 & 40.14 & 40.32 & $*$ \\
$C$ & & & $*$ & 34.25 & 36.30 & 37.21 & $*$ \\
$D$ & & & & $*$ & 39.01 & 36.92 & $*$ \\
$E$ & & & & & $*$ & 35.82 & $*$ \\
$F$ & & & & & & $*$ & $*$ \\
WBF & & & & & & & 42.66 \\
\hline
\end{tabular}

Source: computed from vegetation survey data, 2017.

TABLE 4: Dissimilarity index of plant species in west bank and block A forest of IITA

\begin{tabular}{lccccccc}
\hline Transect & $A$ & $B(\%)$ & $C(\%)$ & $D(\%)$ & $E(\%)$ & $F(\%)$ & BAF (\%) \\
\hline$A$ & $*$ & 29.10 & 32.99 & 51.55 & 45.18 & 46.88 & $*$ \\
$B$ & & $*$ & 41.94 & 48.69 & 41.24 & 42.53 & $*$ \\
$C$ & & & $*$ & 48.98 & 46.73 & 46.37 & $*$ \\
$D$ & & & & $*$ & 44.72 & 46.37 & $*$ \\
$E$ & & & & & $*$ & 47.25 & $*$ \\
$F$ & & & & & & $*$ & $*$ \\
WBF & & & & & & & 40.58 \\
\hline
\end{tabular}

Source: computed from vegetation survey data, 2017.

of $40.58 \%$ while the least value of $29.10 \%$ was recorded between transects $A$ and $B$. According to Ekta [38], more or less uniform environmental conditions are revealed by higher value of similarity index; in contrast, lower value indicates distinct heterogeneity.

\section{Conclusion and Recommendation}

Based on the findings of the study, it can be concluded that there was high diversity of plants (both alpha and gamma diversity) from seventy families in the two forests. Block A forest had the highest number of species (intraspecific or alpha diversity) from fifty-eight families, while west bank forest was high in individual species (gamma diversity) from fifty-six families. Besides, west bank forest was high in all the diversity indices considered apart from alpha and Margalef's diversity indices. It can also be concluded that the similarity indices of plants between west bank forest and block A forest was high for both Sorensen's (above 50\%) and Jaccard (above 40\%). Thus, the two forests are richer and diverse in plant species; adequate protection of the two forests should be a priority to prevent loss of diversity of plants. Removal of poles, firewood, stakes, or any other forest products that may lead to loss of plant diversity and further degenerate the block A forests should be stopped. Development of buffer zone (golf forest could be used as buffer zone) should be made where villagers would be allowed to collect firewood, palm products, vegetables, medicinal plants, and other forest products for their immediate needs. However, they should be restricted to such zones and not allow encroaching into protected areas (west bank and block A forest).

\section{Data Availability}

The raw (primary) data generated for this study were collected from the west bank and block A forest of the International Institute of Tropical Agriculture (IITA) forest. The data that support the findings of this study are available from the corresponding author upon reasonable request.

\section{Conflicts of Interest}

The authors declare that they have no conflicts of interest.

\section{References}

[1] I. A. Ayodele and G. A. Lameed, Essentials of Biodiversity, Power House Press, New york, NY, USA, 1999.

[2] Convention on Biological Diversity, 1992, http://sedac.ciesin. org/entri/texts/biodiversity.

[3] B. F. Swindel, L. F. Conde, and J. E. Smith, "Species diversity: concept, measurement, and response to clearcutting and sitepreparation," Forest Ecology and Management, vol. 8, no. 1, pp. 11-22, 1984.

[4] A. Schuler, "Sustainability and biodiversity-forest historical notes on two main concerns of environmental utilization," Assessment of Biodiversity for Improved Forest Planning, Kluwer Academic Publishers, Dordrecht, Netherlands, 1998.

[5] M. Neumann and F. Starlinger, "The significance of different indices for stand structure and diversity in forests," Forest Ecology and Management, vol. 145, no. 1-2, pp. 91-106, 2001.

[6] M. R. Ardakani, Ecology, Tehran University Press, Tehran, Iran, 2004.

[7] A. E. Magurran, Ecological Diversity and Its Measurement, Princeton University Press, Princeton, NJ, USA, 1988.

[8] D. M. Kashian, B. V. Barnes, and W. S. Walker, "Ecological species groups of landform level ecosystems dominated by jack pine in northern Lower Michigan, USA," Plant Ecology, vol. 166, no. 1, pp. 75-91, 2003.

[9] P. Dansereau, "The origin and growth of plant communities," in Growth in Living 435 System: Proceedings of International Symposium on Growth, M. X. Zarrow, Ed., pp. 573-603, Basic Books, New York, NY, USA, 1960.

[10] B. P. Mishra, O. P. Tripathi, R. S. Tripathi, and H. N. Pandey, "Effects of anthropogenic disturbance on plant diversity and community structure of a sacred grove in Meghalaya, northeast India," Biodiversity and Conservation, vol. 13, no. 2, pp. 421-436, 2004.

[11] R. Fox and K. Rowntree, The Geography of South Africa in a Changing World, Oxford University Press, Oxford, UK, 2000.

[12] B. Groombridge and M. D. Jenkins, World Atlas of Biodiversity: Earth's Living Resources in the 21st Century, University of California Press, Berkeley, CA, USA, 2002.

[13] M. G. Barbour, J. H. Burk, W. D. Pitts, F. S. Gilliam, and M. W. Schwartz, Terrestrial Plant Ecology, Addison Wesley Longman, Boston, MA, USA, 3rd edition, 1998.

[14] C. R. Grooves, Drafting a Conservation Blueprint: A Practitioner's Guide to Planning for Biodiversity, Island Press, Washington, DC, USA, 2002.

[15] T. J. Stohlgren, "Planning long-term vegetation studies at landscape scales," in Ecological Time Series, T. M. Powell and J. H. Steek, Eds., pp. 209-241, Springer Science \& Business Media, Berlin, Germany, 1994.

[16] I. S. Kunene and B. S. Nkosi, A Survey of Information on the Botanical Biodiversity in Swaziland, Swaziland Government/ United Nations Development Programme Report, 1997. 
[17] A. Zobolo and Q. Mkabela, "Traditional knowledge transfer of activities practised by Zulu women to manage medicinal and food plant gardens," African Journal of Range \& Forage Science, vol. 23, no. 1, pp. 77-80, 2006.

[18] A. U. Ezealor, Ed., Critical Sites for Biodiversity Conservation in Nigeria, Nigeria Conservation Foundation, Lagos, Nigeria, 2002.

[19] A. Tenkouano and K. P. Baiyeri, "Adoption pattern and yield stability of banana and plantain genotypes grown in contrasting agro- ecology zone in Nigeria," African Crop Science Conference Proceedings, vol. 8, pp. 377-384, 2007.

[20] H. Wolda, "Diversity, diversity indices and tropical cockroaches," Oecologia, vol. 58, no. 3, pp. 290-298, 1983.

[21] J. C. Onyekwelu, A. J. Adekunle, and S. A. Adeduntan, "Does tropical rainforest ecosystem possess the ability to recover from severe degradation," in Sustainable Forest Management In Nigeria: Lessons And Prospects. Proceedings of the 30th Annual Conference of the Forestry Association of Nigeria Held in Kaduna, Kaduna State, Nigeria. November 2005, L. Popoola, P. Mfon, and P. I. Oni, Eds., pp. 145-163, Forestry Association of Nigeria, Ibadan, Nigeria, 2005.

[22] A. Lawal and V. A. J. Adekunle, "Impact of enrichment planting on biodiversity restoration in degraded forest," in Forestry In the Context Of the Millennium Development Goals Proceedings of the 34th Annual Conference Of the Forestry Association Of Nigeria held in Osogbo, Osun State, Nigeria, L. Popoola, K. Ogunsanwo, and F. Idumah, Eds., vol. 1, pp. 558-571, 2011.

[23] O. C. Ariyo, S. A. Oluwalana, O. Akinyemi, M. O. Ariyo, and O. G. Awotide, "Structure and demographics patterns of woody plant community in IITA forest reserve," Obeche, vol. 29, no. 2, pp. 259-269, 2011.

[24] O. C. Ariyo, S. A. Oluwalana, O. I. Faleyimu, and M. O. Ariyo, "Assessment of vegetation structural diversity and similarity index of IITA forest reserve in ibadan, Oyo state, Nigeria," Agrosearch, vol. 12, no. 2, pp. 135-157, 2013.

[25] A. O. Onefeli, O. H. Opute, and T. I. Oluwayomi, "Biodiversity assessment of okpe sobo forest reserve, delta state," in Proceeding of the 36th Annual National Conference of the Forestry Association of Nigeria, Uyo, Nigeria, November 2013.

[26] O. C. Ariyo, Socio-Economic and Botanic Analysis of West Bank Forest and Block A Forest of IITA, Ibadan, Oyo State, Nigeria, Ph.D. thesis, pp. 1-357, University of Agriculture, Abeokuta, Ogun State, Nigeria, 2018.

[27] L. O. Ojo, Data Collection and Analysis for Biodiversity Conservation: in Practical of the Inception Meeting and Training Workshop on Braaf. Assessment and Monitoring Technique in Nigeria, B. A. Ola-Adams and L. O. Ojo, Eds., pp. 142-145, National Committee of Man and Biosphere, Paris, France, 1996.

[28] H. E. Gauch, Multivariate in Community Ecology, Cambridge University Press, Cambridge, UK, 1986.

[29] E. H. Simpson, Measurement of Diversity Nature, vol. 163, no. 688 , pp. $163-188,1949$.

[30] C. E. Shannon and W. Weiner, The Mathematical Theory of Communication, University of Illinois Press, Champaign, IL, USA, 1964.

[31] E. C. Pielou, An Introduction to Mathematical Ecology, WileyInterscience, Hoboken, NJ, USA, 1969.

[32] R. Margalef, Perspective in Ecological Theory, p. 112, University of Chicago Press, Chicago, IL, USA, 1968.

[33] R. P. McIntosh, "The continuum concept of vegetation," The Botanical Review, vol. 33, no. 2, pp. 130-187, 1967.
[34] E. F. Menhinick, "A comparison of some species diversity indices applied to samples of field insects," Ecology, vol. 45, no. 4, pp. 858-862, 1964.

[35] T. A. Sørensen, A Method of Establishing Groups of Equal Amplitude in Plant Sociology Based on Similarity of Species Content, and Its Application to Analyses of the Vegetation on Danish Commons, I kommission hos E. Munksgaard, Copenhagen, Denmark, 1948.

[36] P. C. Nath, A. Arunachalam, M. L. Khan, K. Arunachalam, and A. R. Barbhuiya, "Vegetation analysis and tree population structure of tropical wet evergreen forests in and around Namdapha National Park, northeast India," Biodiversity and Conservation, vol. 14, no. 9, pp. 2109-2135, 2005.

[37] A. E. Magurran, Measuring Biological Diversity, p. 256, Blackwell Publishing, Oxford, UK, 2004.

[38] S. Ekta, "Comparative analysis of diversity and similarity indices with special relevance to vegetations around sewage drains," World Academic of Science, Engineering and Technology, vol. 6, no. 9, pp. 735-737, 2012.

[39] J. P. Pascal, Wet Ever Green Forests of the Western Ghats of India, French Institute of Pondicherry, Pondicherry, India, 1988.

[40] R. Hengaveld, "Measuring ecological biodiversity," Biodiversity Letters, vol. 3, no. 2, pp. 58-65, 1996.

[41] R. S. De Groot, J. Van der Perk, A. Chiesura, and S. Marguliew, "Ecological functions and socio-economic values of critical natural capital as a measure for ecological integrity and environmental health," in Implementing Ecological Integrity: Restoring Regional and Global Environmental and Human Health. NATA-Science Series, IV, Earth and Environmental Science, P. Crabbe, A. Holland, L. Ryszkowski, and L. Westra, Eds., vol. 1, pp. 191-214, Springer Science \& Business Media, Berlin, Germany, 2000.

[42] N. Brown, S. Jennings, and T. Clements, "The ecology, silviculture and biogeography of Mahogany (Swietenia macrophylla): a critical review of the evidence," Perspectives in Plant Ecology, Evolution and Systematics, vol. 6, no. 1-2, pp. 37-49, 2003.

[43] J.-R. Makana and S. C. Thomas, "Impacts of selective logging and agricultural clearing on forest structure, floristic composition and diversity, and timber tree regeneration in the ituri forest, democratic republic of Congo," Biodiversity and Conservation, vol. 15, no. 4, pp. 1375-1397, 2006.

[44] O. C. Ariyo, Economic Botany Survey of International Institute of Tropical Agriculture (IITA) Forest, Ibadan, Nigeria, p. 61, MF, Dissertation Department of Forestry and Wildlife Management, Federal University of Agriculture, Abeokuta, Ogun State, Nigeria, 2007.

[45] A. O. Isichei, "Biodiversity conservation and sustainable development: ecology assessment and monitoring of biodiversity in Nigeria," in Practical of the Inception Meeting and Training on BRAAF. Assessment and Monitoring Technique in Nigeria, B. A. Ola-Adams and L. O. Ojo, Eds., pp. 107-115, National Committee of Man and Biosphere, Paris, France, 1996. 